\title{
Ecotourism; the Multiplier Waves: A Learning Experience of Thenmala Eco-Tourism Project in Kerala, India.
}

\author{
R. Ajil Babu \\ (Research Scholar-Economics, Dept. Economics, University College Trivandrum, University of Kerala, India)
}

\begin{abstract}
Realizing the uncompensated catastrophe that modern tourism generates, the protagonists of sustainable development emphasize the need for making resilience to nature; today the option is 'Nature Ecotourism, i.e. tourism basically depending natural attractions in a pollution free environment. The present paper focuses on the Thenmala Eco-tourism Project in India which is India's first planned Eco-tourism destination due to its unique vistas, bio diversity and functioning. The Thenmala Eco-tourism shares its resources with the famous Shendurey Widlife Sanctuary at the foothills of Western Ghats. The prime objective of Thenmala Ecotourism projects is to minimize the negative impacts and create an economic and social environmental which generates greater economic benefit for local people and enhances the well-being of the host communities. It provides more enjoyable experience for tourism through more meaningful connections with local people and a greater understanding of local, cultural, social and environmental issues. The paper discusses the economic, ecological and social impact of Thenmala Eco-tourism, i.e., in a densely populated State like Kerala, where the arrival of tourists is increasing year after year, how tourism is well maintained without degrading the ecosystem is the hypothesis of the paper.
\end{abstract}

Keywords: Ecological Sustainability, Eco-tourism, Multiplier, Opportunity Cost, Sustainable Development,

\section{Introduction}

Sustainable development, now comprehends an assortment of development schemes in social, cleantech (clean energy, clean water and sustainable agriculture) and human resources segments, having caught the attention of both the Central and State governments and also public and private sectors.

Sustainable tourism, an integral part of Sustainable development, is an industry committed to making a minimum impact on the environment and local culture, while assisting to spawn employment for local people in present as well as future. The targeting shot of sustainable tourism is to confirm development that brings a positive experience to the local people, tourism companies and the tourists' themselves. It is a passage through other people's lives other people's culture and other people's places. [IHRA]

Global economists forecast, continuing international tourism growth, ranging between 3 and 6 percent annually, depending on the location. As one of the world's largest and fastest growing industries, this continuous growth will place great strain on remaining biologically diverse habitats and indigenous cultures, which are often used to support mass tourism. Tourists who promote sustainable tourism are sensitive to these threats and pursue to protect tourist destinations.

Sustainable tourism can reduce the negative impact of tourism in many ways, including:

- Construction and design, suitable to local environment.

- Contributing to intercultural understanding and tolerance.

- Supporting the integrity of local cultures by favoring businesses which conserve cultural heritage and traditional values.

- Supporting local economies by purchasing local goods and participating with small, local businesses.

- Conserving resources by seeking out businesses that are environmentally conscious, and by using the least possible amount of non-renewable resources.

\section{Thenmala Ecotourism Project}

Kerala, the narrow strip of green land, lies in the southern part of Indian peninsular is branded as 'God's Own Country' in the world tourism map. The state has bagged good number of national and international honors for her coverable performance in tourism, launched the first planned ecotourism in India [in Thenmala], by incorporating community participation in tourism and executed responsible tourism for socio, economic and environmental empowerment.

Thenmala is a small village at the foothills of Western Ghats and for the most part, a forest area with a lot of human interventions at the edge. Peppara dam, of Kallada irrigation projects of the State is located here. The water spread area of this basin is $22 \mathrm{sqkm}$. The famous Schenduruni Wildlife Sanctuary, the most vital resource of Thenmala ecotourism project, is established around this water body. 
Thenmala ecotourism project won the prestigious Pacific Asia Travel Association [PATA] gold award for 2003-04 and the National Tourism Awards for the most ecofriendly organization in 2001-02, and the best ecotourism practices in 2003-04. The World Tourism Organisation [WTO] has incorporated Thenmala ecotourism project in the publication "Sustainable Development of Ecotourism; a compilation of good practices in SMES". In view of that there are about 64 good practices from 47 countries world over and Thenmala ecotourism is the only venture that has been included from India.

\subsection{Economic Impacts}

The basic tenet of a positive economic activity is the maximization of benefits and minimization of costs. Ecotourism encompasses direct, indirect as well as opportunity costs. While the expense for establishing and maintaining a nature tourism spot is direct, the damage caused by nature tourism to society is indirect. A well planned nature tourism arrangement can minimize all these cost substantially.

The economic value of ecotourism is reflected in generating income and employment in the economy. While this is a macro picture of the economic benefits, the ecotourism destination in particular, springs income from other sources also. Last but not least community participation is the hallmark of ecotourism. It works as a toll for ensuring regional development from a sustainable perspective.

The major economic benefit of Thenmala ecotourism is its potential to spawn revenue as well as employment. This economic potent is not limited within the geographic boundaries of the destination alone, but it has been found that peripheral regions do benefit from this activity. The activities involve expenditure from part of the visitors, which could contribute significantly to the income and wealth of the local community. Of the amount spend by every visitor within the destination, commissions to agents and guides and profits to the companies and the business establishments' account for the largest share, which is followed by wages to staffs of these establishments and other related activities.

Even in cases where the capacity to generate direct revenue and employment is not as substantial as would sensibly be expected, other inflows that can here a significant hearing up on the wealth and living standard of the local community. For e.g. in Thenmala a lower magnitude of direct tourist expenditure could well be supplemented by tourism related sales of forest products, handicrafts and similar artifacts which by itself supported the indigenous economy by contributing sustainability to revenue.

On the basis of income, employment and revenue to the government, the economic impact of Thenmala ecotourism can be analysed.

\section{Table 1}

Number of total - both domestic and foreign tourists arrival to Kerala

\begin{tabular}{|l|l|l|l|l|}
\hline Year & $\begin{array}{l}\text { No. of domestic } \\
\text { tourists visits }\end{array}$ & Percentage increase & $\begin{array}{l}\text { No. of foreign } \\
\text { tourists }\end{array}$ & $\begin{array}{l}\text { Percentage } \\
\text { increases }\end{array}$ \\
\hline 1999 & 4888287 & 9.07 & 202173 & 6.44 \\
\hline 2000 & 5013221 & 2.56 & 209933 & 3.84 \\
\hline 2001 & 5239692 & 4.52 & 208830 & -0.53 \\
\hline 2002 & 5568256 & 6.27 & 232564 & 11.37 \\
\hline 2003 & 5871228 & 5.44 & 294621 & 26.68 \\
\hline 2004 & 5972182 & 1.72 & 345546 & 17.28 \\
\hline 2005 & 5946423 & -0.43 & 346499 & 0.28 \\
\hline 2006 & 6271724 & 5.47 & 428534 & 23.70 \\
\hline 2007 & 6642941 & 5.92 & 515808 & 20.37 \\
\hline 2008 & 7591250 & 14.28 & 598929 & 16.11 \\
\hline 2009 & 7913537 & 4.25 & 557258 & -6.96 \\
\hline 2010 & 8595075 & 8.61 & 659265 & 18.31 \\
\hline 2011 & 9381455 & 9.15 & 732985 & 11.18 \\
\hline
\end{tabular}

Source: Various issues of Economic Reviews, State Planning Board, Gov. of Kerala

The year 2010-11 has been recorded as a year of revival compared to the previous years. International Tourist arrival continued to decline due to the impact of Global Economic crisis in the previous years. But the year 2011 marked a significant improvement. The number of foreign tourists arrived in Kerala in the year 201011 is 659265 against 557258 in 2009-10. It shows an increase of 18.31 per cent over the previous year. During the last year Kerala has contributed $11.81 \%$ of the total foreign tourist arrivals to India

A 11 per cent increase in foreign tourist arrivals and 9.15 per cent increase in domestic tourist arrivals to Kerala had been registered during the year 2011despite a host of negative factors.

The foreign exchange earnings from tourism had also gone up from Rs. 3797.37 crores in 2010 to Rs. 4221 crores registering a 11.18 per cent increase. The total revenue, both direct and indirect, from tourism touched Rs. 
19,037 crores last year compared to Rs. 17,348 crores in 2010 showing an increase of 9.74 per cent.

.Table 2

Number of tourist arrivals in Thenmala

\begin{tabular}{|c|c|c|}
\hline Financial year & $\begin{array}{c}\text { Number of Tourists } \\
\text { visited }\end{array}$ & $\begin{array}{c}\text { Revenue Generated (in } \\
\text { Rs ) }\end{array}$ \\
\hline $2000-01$ & 26148 & 445437 \\
\hline $2001-02$ & 41161 & 1138839 \\
\hline $2002-03$ & 65075 & 2147985 \\
\hline $2003-04$ & 118404 & 4044571 \\
\hline $2004-05$ & 104622 & 3563820 \\
\hline $2005-06$ & 114443 & 3926430 \\
\hline $2006-07$ & 120178 & 4954459 \\
\hline $2007-08$ & 104758 & 4602536 \\
\hline $2008-09$ & 92191 & 4813440 \\
\hline $2009-10$ & 114714 & 5535195 \\
\hline $2010-11$ & 130961 & 7050000 \\
\hline
\end{tabular}

Source: Various issues of Economic Reviews, State Planning Board, Gov. of Kerala

The number of tourists in Thenmala is increasing year after year. From these tables we can conclude that Kerala can be developed as a major ecotourism destination. As visitation to natural areas increase including ecotourism destination so does the demand for travel professionals to accommodate the tourists (Hawkins and Lamouter 2001). In the last few years, the state witness a tremendous increase in travel professional, such as travel and tour operators, who market eco-tourism destination of Kerala both outside as well as within the country. Today, Eco tourists thus have a lot of better options and reasons to travel to our state. Hence in Kerala, the number of tourists preferring eco-destination increasing year after year

\subsection{The Multiplier effect}

Economic impact of Thenmala ecotourism also have a multiplier effect, where the benefits of direct income and employment is internally circulated within the economy to generate additional benefits that in turn could create related income opportunities. In contrast to the other forms of tourism, the multiplier effect of ecotourism is even more sizable since ecotourism is expected to be not only environmentally consciousness, but also aesthetically responsible. In the case of Thenmala, the visitors prefers local food and other products, where their payments are subsequently circulated internally for the payment of wages to hostel staffs etc, which itself influences another chain of economic activity where indigenous products are purchased by these staffs with their wages. Unlike any other tourism destinations in Kerala, there is not even a single international or even star hotels situated In Thenmala. Money is locally circulating here. It is not a resisting that Eco tourists do exhibit a sort of responsibility where they conscientiously try to support the local economy of the destination they visit.

\subsection{Ecological Impact}

The concept ecotourism comprise two components. The descriptive component means that the activity is specifically based on the nature being the epicenter of all that happens. Alternately, the value based cog means the existence of an educational potent, as well as the need for it being ecologically sustainable. We can see both this component in the case of Thenmala ecotourism project.

In Thenmala, ecotourism activity is not only non-damaging and non-degrading, but also it contributed directly to the management of protected area. In Thenmala the Schenduruni Wildlife Sanctuary is well maintained.

The most famous attractions in Thenmala, the Elevated Walkway, which fly over the rocky areas through the canopy of large trees, is created without debasing the forest ,i.e. without cutting a single tree.

An alternative scenic beauty, the sculpture garden is located at the midst of the forest without any damages to the ecology.

The natural trail, in Thenmala is made with minimum intervention and is just adequate for the nature traveller to trail on.

The battery operated boats, used in the lake, signifies the importance attached to the non-polluting source of energy.

Thenmala ecotourism zones are identified as plastic free zones, minimizing the area of plastic by not allowing plastic products in the concerned area. 
To ensure conservation of heritage and environment in planned and regulated manner, the government wants to create zero-waste project and special tourism zones in Thenmala. The project thus ensures ecological sustainability.

\subsection{Social Impact}

As ecotourism is a purposeful travel to natural areas to understand the nature and natural history of the environment, taking care not to alter the integrity of eco system, while producing economic opportunities that make the conservation of natural resources beneficial to local people.

The social impact of Thenmala eco-tourism project, explained below is on the basis of discussions with the local people, on how they benefited from ecotourism.

There were about 500 households living in Thenmala [EIA report]. Their major job opportunities lie in the area of providing travel, accommodation and guiding the tourists. The Thenmala Eco-tourism Promotion Society [TEPS] which is an institutional arrangement to undertake ecotourism activities has already given training to local people in the field of Guiding. Other opportunities lies in the areas of souvenir development, small shops ,hotels, selling of local handicraft, local forest produces, preforming local art forms, restaurants etc.

There are certain small shops and cafeterias situated here owned by the government. The Kudumbashree (unit of village women) units of Thenmala Gram Panchjayath recruits peoples to these shops with a minimum rate of investment and a fixed monthly rent plus electricity bill.

The Eco Development Committees formed by the Forest Department consists of local communities for the conduct of tracking, bird watching, trails and conservation of the forest.

The Thenmala Ecotourism Promotion society also supports the community participation initiatives at Palaruvi, a famous water fall near Thenmala.

The people questioned, pointed out that the Forest Department has specific programs for ensuring local benefits by entrusting the management of ecotourism centers to Vana Sameekshana Samadhi, a body of local people who are interested in the vanity of the ecosystem protection, for this purpose . According to them, the government and concerned departments should formulate suitable strategies for the development of Thenmala ecotourism project.

A major drawback, stressed by almost all the persons interviewed, is the seasonality of tourism. The tourist season is started from October to march, i.e. 6 months. During these period people will be benefitted from the sale of forest products and also from shops, hotels etc., and earns income. But their situation in the off seasonal period is pathetic. Only domestic tourists visit Thenmala during this period. Shops and hotels may sometimes be closed. The shop keepers will get a lower income during this period, even though he has to pay rent. Sometimes they might quit from their job, hence there is a kind of seasonal unemployment existing here.

\section{Conclusion}

Despite of all the negative factors we can consider Thenmala ecotourism project as the best example for designing, implementation and conservation of natural recourses. Local involvement in planning, designing and subsequent employment at Thenmala could be considered as good example for community participation. In short Thenmala ecotourism project is economically beneficial, ecologically sustainable and locally preferable. The functioning of Thenmala ecotourism project could be enhanced by evolving a clear cut strategy to promote public and private partnership so as to develop ecotourism, preparing monitoring mechanism for ecotourism products, establishing environment education centers and eco-development committee in tourism areas and initiating ecofriendly camps for making aware of the concept among the peoples

\section{References}

[2] Sharma, Shashi Prabha (2006). 'Tourism and Environment, Concepts, Principles and Approaches', Kanishka Publishers, New Delhi.

[3] Clarke, J (1997). 'A Framework of Approaches to Sustainable Tourism', Journal of Sustainable Tourism.

[4] Dhulasi Birundha V (2003). 'Environmental Challenges towards tourism', Kanishka Publishers, New Delhi.

[5] Government of Kerala, Economic Review (2011), State Planning Board, Thiruvananthapuram.

[6] Goodwin H. (1996), In Pursuit of Eco-tourism, Biodiversity and Conservation Government of Kerala, Kerala Tourism Statistics (2010), Department of Tourism, Thiruvananthapuram.

[7] Reports of Thenmala Ecotourism Promotion Society Kerala Institute of Tourism and Travel Studies (KITTS) (2006), Issues and Trends in Ecotourism Development in India, Published by V.Rajeevan IRPS Director, KITTS, TVPM www.thenmalaecotourism.com/nature.

[8] Directorate of eco-tourism, Government of Kerala, Trivandrum Kerala Development Report 2012 